DOI 10.4467/2543733XSSB.17.022.8320

MACIEJ KAWKA

Uniwersytet Jagielloński

\title{
KREOWANIE TOŻSAMOŚCI NARRACYJNEJ - STATUS I KORPUS JĘZYKA MACEDOŃSKIEGO
}

Słowa kluczowe: Bałkany, Macedonia, język macedoński, narracje transmedialne, tożsamość narracyjna

\section{Wstęp}

Spory o prawdziwą lub tylko wyobrażoną ${ }^{1}$ tożsamość narodów zamieszkujących dzisiejsze terytorium Bałkanów mają aspekt nie tylko rzeczywisty jako splot zdarzeń i faktów historycznych oraz współczesnych przemian, których nie należy lekceważyć, ale także wymiar transmedialnych opowieści ${ }^{2}$ o tożsamości. Te dwie płaszczyzny istnienia procesów tożsamościowych bądź współistnieją, bądź konkurują ze sobą, a w każdym razie się przenikają. Dzisiaj jednak - jak się wydaje - przeważa ten drugi aspekt tworzenia - często imaginacyjnych i samoidentyfikujących - narracji lub transmedialnych autonarracji o pochodzeniu i tożsamości. W tym kontekście pojawiają się dwa podstawowe pytania badawcze:

1) tekstowy (narracyjny) obraz Bałkanów został wykreowany przez Europę (kraje europejskie i Europejczyków), czy przez same państwa bałkańskie w procesach autonarracyjnych i w celu swojej samoidentyfikacji?

2) jak długo Bałkany pozostaną tajemnicą dla ich europejskich sąsiadów? Niejednorodność kulturowa regionu wydaje się najważniejszą, ale nie jedyną tego przyczyną.

\section{I. Źródla narracji transmedialnych}

Przemiany społeczno-polityczne i gospodarcze na Bałkanach, w tej części Europy, która była do tej pory we władaniu totalitarnych reżimów politycznych, doprowadziły bądź to do aktualizacji, bądź to reprodukcji języka (kodu) dyskursów oraz narracji kulturowych

\footnotetext{
${ }^{1}$ Zob. M. To d o r o v a, Batkany wyobrażone, przeł. M. Budzińska, P. Szymor, Wydawnictwo Czarne, 2008.

${ }^{2}$ Autorzy powołują się tu na znaną pracę $\mathrm{H}$. J en kin s a, Kultura konwergencji. Zderzenie starych $i$ nowych mediów, Warszawa 2007.
}

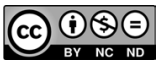


i narodowych. Teraz ich celem stało się nie tyle utrzymanie dawnych, starych i zamierających narracji historyczno-politycznych, ile ich rekonstrukcje w celu zbudowania całkowicie nowych tożsamości. Procesy te działy się, i dzieją się dzisiaj, zazwyczaj w przestrzeni zdarzeń historycznych lub politycznych - jako skutek konkretnych decyzji podjętych przez władze określonych państw lub jako rezultat ruchów społecznych i narodowych - w przeciwieństwie do takiej tożsamości narodowej, która nie powstaje w wyniku przemian społeczno-politycznych i ma niewiele wspólnego z rzeczywistym światem wydarzeń, rodzi się bowiem w świecie narracji i opowieści o zdarzeniach i - być może w pewnym stopniu - na ich kanwie. Jest to świat opowieści o zdarzeniach, ale nie świat ich samych.

Spory o tożsamość narodów zamieszkujących dawniej i współcześnie terytorium Bałkanów mają zatem wymiar nie tylko rzeczywisty jako rezultat splotu zdarzeń i faktów historycznych (wojen i zbrojnych powstań), ale także współczesnych przemian (transgresji i transformacji ustrojowych), które dzisiaj w kontekście burzliwego rozwoju cyfrowych technologii przekazu warto również rozpatrywać w wymiarze transmedialnych narracji i intertekstualnych opowieści o procesach samoidentyfikacji. Chociaż jak było wspomniane, procesy te przebiegają zazwyczaj w przestrzeni zdarzeń historyczno-politycznych i społecznych - jako wynik decyzji władz określonych państw lub rezultat ruchów społecznych i narodowych, dzisiaj w dużej mierze są kreowane przez transmedialne opowieści i mają niewiele wspólnego z rzeczywistym światem zdarzeń, i dzieją się prawie wyłącznie $\mathrm{w}$ mediach - dzięki tworzonym przez nie narracjom transmedialnym, a nie w świecie rzeczywistym. Wówczas są próbą kreowania „nowej” rzeczywistości polityczno-społecznej, będącej efektem procesów mediatyzacyjnych, tzn. zapośredniczania pamięci o przeszłości lub teraźniejszości przez media, przy czym one same są definiowane nie tylko w wąskim rozumieniu jako media masowe (prasa, radio telewizja, Internet), ale jako wszelkie nośniki pamięci (od źródeł historycznych, muzeów, pomników, uroczystości rocznicowych aż po opowieści transmedialne, film, teatr czy szeroko rozumianą sztukę). W tym kontekście narracje transmedialne (transmedia storytelling) to wielowątkowe i zróżnicowane historie, opowiadane (zapośredniczane) za pomocą różnych form przekazu (film, platformy społecznościowe, gry komputerowe, komiksy itp.).

Pierwszy - świat zdarzeń i drugi - świat transmedialnych opowieści o zdarzeniach mogą mieć miejsca wspólne, bardziej lub mniej spójną czasoprzestrzeń i bliskie lub odległe punkty widzenia. Ten drugi świat, to także nie świat tożsamości istniejącej w rzeczywistości (poznawczej, mentalnej bądź referencyjnej), nawet jako mentalne jej modele i wirtualne obrazy, ale świat tożsamości narracyjnej, tożsamości „opowiadanej”, realnie manifestującej się w opowieściach o tożsamości (narodowej), tożsamości istniejącej wyłącznie w tekstach streszczających wiedzę o historii, o polityce, o społeczeństwie, o kulturze lub folklorze, o obyczajach danego narodu, także w tekstach naukowych, popularnonaukowych, literackich, paraliterackich lub medialnych (dziennikarskich). Taki rodzaj tożsamości nazwać by można tożsamością tekstową, tekstualną lub narracyjną.

Największą reprezentatywność - ze względu na łatwość dotarcia z treściami „tożsamościowymi" do odbiorcy i ich niewielką głębię merytoryczną, ale wyjątkową moc perswazyjną - uzyskuje ten typ tożsamości „narracyjnej”, który występuje w różnego rodzaju przekazach dzięki tworzonym przez ich nadawców (autorów) i odbiorców narracjom transmedialnym. 
W swojej podstawowej formie cyfrowe opowieści to także multimodalne projekty (złożone z fotografii, tekstu i nagrania głosu narratora, lub amatorskie nagrania wideo na platformie Youtube) czy też skomplikowane projekty architektoniczne (Projekt Skopje 2014). I to dzięki rozwojowi Internetu i nowych mediów cyfrowych możemy opowiedzieć naszą historię na wiele różnych sposobów, docierać do większej liczby osób i angażować je we wspólne tworzenie opowieści o tożsamości - w obrębie dwóch przenikających się światów - realnego, w dużej mierze zapośredniczonego i zmediatyzowanego oraz wirtualnego.

\section{Rodzaje macedońskich narracji tożsamościowych}

W sytuacji macedońskiej można wyróżnić trzy rodzaje narracji tożsamościowych, które w różnych mediach występują w rozmaitym nasileniu, tworząc transmedialne opowieści.

Pierwsza narracja dotyczy tezy, że naród macedoński wywodzi się ze słowiańskich plemion, przybyłych na Półwysep Bałkański na przełomie VI i VII wieku n.e.

Drugi rodzaj narracji można określić terminem używanym w macedońskiej historiografii i publicystyce jako „antykwizacja”, która polega na podkreślaniu pochodzenia współczesnych etnicznie Macedończyków od ich starożytnych (antycznych) przodków.

Trzeci rodzaj narracji transmedialnej to połączenie dwóch poprzednich opowieści. Jej twórcy starają się połączyć dwa poprzednie nurty, twierdząc, że naród macedoński powstał w wyniku specyficznego połączenia (symbiozy) antycznych Macedończyków i Słowian.

W macedońskich tekstach opartych głównie nie na źródłach historycznych, ale też na innych równoległych lub wcześniejszych przekazach, dominują tezy, że tożsamość macedońska ma co najmniej kilka źródeł i jej obraz został skonceptualizowany w postaci przynajmniej pięciu pojęć (profili prototypowych) czy też modeli (obrazów) mentalnych:

- pojęcie Macedończyka w starożytności - Herodot,

- pojęcie Macedończyka Słowianina - profil dominujący w systemie wiedzy,

- pojęcie Macedończyka jako przedstawiciela ludności niesłowiańskiej lub ,przedsłowiańskiej" - profil antyczny,

- pojęcie Macedończyka od powstania nazwy Macedonii w historii nowożytnej,

- pojęcie Macedończyka - mieszkańca dzisiejszej Republiki Macedonii jako kontynuatora etnosu staromacedońskiego.

Obecnie pojawiają się także poglądy, że Macedonia ma tożsamość dwunarodową, w tej narracji nie mówi się bezpośrednio, o jaką tożsamość chodzi, jednak nietrudno się domyślić, że chodzi o tożsamość macedońską i albańską ${ }^{3}$.

${ }^{3} \mathrm{~W}$ wywiadzie udzielonym tygodnikowi „Republika” przewodniczący partii SDMS (СДМС - Социјалдемократски сојуз на Македонија) Zoran Zaev sformułował pewną bardzo ważną i niebezpieczną polityczną tezę, że Macedonia ma dwunarodową tożsamość. Zapytany o potrzebę zmiany Konstytucji Macedonii, w związku z problemem nazwy państwa, stwierdził, że Macedonia nie może się poważyć na zmianę dwunarodowej tożsamości (Во интервју за неделникот „Република” претседателот на СДСМ, Зоран Заев искажа една многу сериозна и опасна политичка теза дека Македонија има двонационален идентитет. Запрашан за потребата од менување на Уставот на РМ по прашањето за името, тој посочува дека Македонија не смее да го менува двонационалниот идентитет) Македонија има двонационален идентитет! https://www.youtube.com/watch?v=iJEXvI4Ri24 (dostęp: 10.10. 2016). 


\section{Narracje uwzględniające status języka narodowego, zasięg użycia i jego korpus}

Co najmniej dwa elementy tworzą transmedialny obraz macedońskiej tożsamości narodowej w wymiarze językowym. Są to:

1) status języka narodowego i zasięg jego użycia,

2) korpus języka narodowego.

\section{A. Status języka}

Pomijając sprawę oficjalnego użycia języka, czyli jego pełnego stosowania w administracji i edukacji na wszystkich poziomach, w sprawie statusu języka rozważane są dwie możliwości:

- używanie języka jako drugiego lub trzeciego języka urzędowego na całym terytorium państwa,

- graniczone oficjalne użycie - wykorzystanie języka w lokalnych samorządach, a może na poziomie regionalnym.

Stąd też pochodzi określenie statusu języka jako:

- pierwszego języka urzędowego w państwie (czy to w państwie unitarnym, czy federacyjnym)

- lub jako języka oficjalnego w granicach określonych jednostek państwa, który jest zazwyczaj używany obok języka urzędowego.

\section{B. Korpusy języka}

Korpus danego języka obejmuje i dopuszcza istnienie kilku wariantów językowych:

1) standaryzowany - język / język literacki;

2) dialekt (zwykle jest to język danego regionu jako język regionalny i lokalny język, języki używane w pewnych miejscowościach, miastach, wsiach, częściach miasta itp.);

3) etnolekt - używany przez wyodrębnioną grupę etniczną; co do etnolektów istnieje spór, czy są to języki, czy dialekty (meglenorumuński);

4) subdialekt, interdialekt, substandard wiejski - powstają w strefie przejściowej pomiędzy gwarami a językiem ogólnym. Na przykład dialekt południowokaszubski jako jeden z trzech zespołów gwarowych języka kaszubskiego: południowego, południowo-wschodniego i południowo-zachodniego.

Style, ortografia, frazeologia potoczna, żargon nie są związane z korpusem. 


\section{Korpusy i status języka macedońskiego poza terytorium Macedonii}

W Republice Albanii macedoński język jest rozpoznawalny tylko jako autonomiczny język społeczności macedońskiej, czyli tylko macedońskich chrześcijan, a nie macedońskich muzułmanów.

W Republice Serbskiej język macedońskiej częściowo rozpoznawany jako lokalny język wspólnoty macedońskiej - tylko częściowo jest uznany za autonomiczny język macedońskiego narodu, ponieważ w niektórych kręgach naukowych, a zwłaszcza w środowiskach duchownych, macedoński język jest postrzegany jako wariant języka serbskiego.

W byłej Socjalistycznej Prowincji Autonomicznej Kosowo (obecnie Republika Kosowa) macedoński język ma również status lokalny. Podobnie jest w Republice Czarnogóry - jest on rozpoznawany jako autonomiczny język macedońskiego narodu poza granicami kraju.

W Republice Bułgarii macedoński język częściowo ma status lokalnego wariantu języka bułgarskiego (Macedonia Piryńska). Macedoński język nie jest rozpoznawany jako autonomiczny język macedońskiego narodu, a w państwowych, naukowych i duchownych kręgach uchodzi za pisany wariant języka bułgarskiego.

W Turcji, Słowenii, Rumunii, Chorwacji oraz Bośni i Hercegowinie macedoński język ma status języka lokalnego i jest rozpoznawany jako autonomiczny język macedońskiego narodu.

W Grecji macedoński język nie jest rozpoznawany jako autonomiczny język narodu macedońskiego ani przez państwo lub kręgi naukowe, ani przez ortodoksyjne środowiska duchownych. Tylko część liberalnej greckiej inteligencji (przetłumaczono dzieła kilku pisarzy i książkę Krste Misirkova pt. Za makedonckite raboti) rozpoznaje język macedoński jako autonomiczny język narodu macedońskiego. Częściowo macedoński ma status języka lokalnego (np. w miejscowości Ovcharani ${ }^{4}$ w okolicy Lerinu).

Czy istnieje niebezpieczeństwo zaniku języka macedońskiego w krajach, gdzie Macedończycy stanowią mniejszość? Analiza korpusu i użycia języka macedońskiego pokazuje, że liczba użytkowników tego języka w krajach ościennych stale spada i może on tam zniknąć po pewnym czasie.

\section{Typy bałkańskich narracji transmedialnych - historycznych, kulturowych, narodowych, politycznych itp. według statusu i korpusu języka}

Typy bałkańskich narracji transmedialnych w bardzo poważnym stopniu konstytuują spory o tożsamość narodową z punktu widzenia historii kultury, polityki. Z tego punktu widzenia są to narracje: serbskie i chorwackie, bułgarskie i macedońskie, greckie i macedońskie, serbskie i kosowskie, macedońskie i albańskie. Te ostatnie bardziej dotyczą statusu języka albańskiego i relacji między nimi w Macedonii niż tożsamości narodowej, choć dominacja języka może wpływać na samookreślenie Macedończyków.

\footnotetext{
${ }^{4}$ https://www.youtube.com/watch?v=BsFn-dpRroA (dostęp 10. 10. 2016).
} 
Analiza bałkańskich narracji i dyskursów na temat tożsamości narodowej - z punktu widzenia stanu języka i danych na temat jego korpusu - wyznacza różnice w odbiorze tych samych wydarzeń, poglądów, stereotypów i mitów w zależności od kraju oraz określa rolę każdego z nich w procesie wykreowania współczesnego obrazu Bałkanów w zakresie poczucia tożsamości przez poszczególne narody i państwa bałkańskie.

Poszczególne transmedialne narracje narodowe występują w różnych aspektach jako:

1) mity narodowe przekształcające się w mity polityczne w procedurach narracyjno-dyskursywnych, i tym samym odgrywające ogromną rolę w kreowaniu tożsamości dla poszczególnych państw bałkańskich,

2) bałkańskie transmedialne narracje narodowe występują zarówno na poziomie lokalnym (por. Ovcharani), jak i na poziomie dwustronnym: macedońsko-greckim, serbsko-chorwackim, serbsko-kosowskim, oraz na europejskich i dalszych poziomach międzynarodowych (Turcja, Rosja, USA).

Należy pamiętać, że przy określaniu tożsamości narracyjnych konieczne są:

- analizy transmedialnych narracji, udokumentowane materiałami zaczerpniętymi z oficjalnych wypowiedzi polityków i przedstawicieli mediów krajowych i międzynarodowych, a także badaniami opinii publicznej, doniesieniami medialnymi i oświadczeniami złożonymi przez wpływowych intelektualistów z całego regionu bałkańskiego i międzynarodowych środowisk opiniotwórczych, umożliwiającymi ujęcie całości narracji narodowych wybranych państw lub regionów w porównawczych perspektywach: bałkańskiej, polskiej oraz z pozycji szerszego kręgu europejskiego i pokazującymi różnice lub podobieństwa w odbiorze tych samych wydarzeń, poglądów, stereotypów i mitów w zależności od kraju, a w konsekwencji pozwalającymi na zbadanie roli każdego z nich w wykreowaniu dyskursywno-narracyjnego obrazu Bałkanów w perspektywie rzeczywistej lub jedynie mentalnej czy medialnej (transmedialnej);

- analizy językoznawcze i semiotyczne dyskursów kulturowych i narodowych oraz ich rodzajów, mające na celu: ukazanie, jak tworzą one bądź modernizują tożsamości kulturowe i narodowe starych i nowo ,zaprojektowanych” (Kosowo) państw bałkańskich; także uwidocznienie różnic w odbiorze tych samych wydarzeń, tekstów, poglądów, stereotypów i mitów w zależności od kraju; ponadto zbadanie roli każdego z nich (dyskursy: macedońskie, serbskie, boszniackie, czarnogórskie) lub rekonstrukcję (dyskursy bułgarskie) w procesie wykreowania językowego obrazu Bałkanów;

- analiza kognitywna postrzegania krajów byłej Jugosławii - ze szczególnym naciskiem na Serbię, Macedonię, Bośnię i Hercegowinę, Chorwację - przez europejskich sąsiadów oraz Europę, Rosję i USA, głównie na materiale doniesień prasowych i medialnych. Jakie językowe obrazy tworzyli i tworzą, które z nich były wspólne i jaki miało to wpływ na bałkańskie konflikty i nieporozumienia?

- interpretacja materiałów archiwalnych, dokumentów (kwerendy archiwalne), literatury naukowej, programów i manifestów politycznych i społecznych, wydarzeń historycznych, z uwzględnieniem eksperymentu asocjacyjnego, doniesień medialnych (prasa, radio, tv, Internet), literatury pięknej; 
- kognitywne badanie językowego obrazu świata, semiotyczna analiza dyskursu (ilościowa i jakościowa), przeprowadzenie eksperymentu asocjacyjnego, którego wynikiem byłby np. Polsko-serbsko-macedoński słownik asocjacyjny. W zakresie badania skojarzeń korzystna jest rekonstrukcja słownika umysłowego dla poszczególnych języków oraz metoda dyferencjału semantycznego Charlesa Osgooda;

- wykorzystanie kategorii punktu widzenia do analizy wartości ukrytych w językowo wykreowanym obrazie świata jako walki poszczególnych podmiotów działających w analizowanych społeczeństwach;

- wykorzystanie do analizy narodowych korpusów językowych [Polski Korpus Narodowy, Chorwacki Korpus Narodowy, Rosyjski Korpus Narodowy, internetowy korpus (WebCorpLive), Korpus Gralis];

- kwerenda materiałowa w bibliotekach krajowych (Biblioteka Jagiellońska, Biblioteka UW, Archiwum Akt Nowych);

- kwerenda materiałowa w sieci internetowej.

\section{Typy bałkańskich dyskursów kulturowych i narodowych}

Spory o tożsamość narodową, historyczną, kulturową, polityczną powodują wykreowanie w obrębie poszczególnych narracji narodowych kolejnych dyskursów tożsamościowych o charakterze binarnym: serbskiego i chorwackiego, bułgarskiego i macedońskiego, greckiego i macedońskiego, serbskiego i kosowskiego itp.

Rezultatem analizy bałkańskich dyskursów o tożsamości kulturowej i narodowej jest wykazanie różnic w odbiorze tych samych wydarzeń, poglądów, stereotypów i mitów w zależności od kraju oraz określenie roli każdego z nich w procesie wykreowania współczesnego obrazu Bałkanów w zakresie poczucia tożsamości przez poszczególne państwa bałkańskie oraz ich porównanie np. z polskim dyskursem narodowym. We wspomnianej analizie należałoby uwzględnić:

- dyskurs serbski,

- dyskurs chorwacki,

- dyskurs boszniacki,

- dyskurs czarnogórski,

- dyskurs macedoński,

- dyskurs bułgarski,

- dyskurs słoweński.

Poszczególne dyskursy narodowe można zatem rozpatrywać w różnych aspektach jako:

1) mity narodowe przekształcające się w mity polityczne w procedurach dyskursywnych, i tym samym odgrywające ogromną rolę w kreowaniu tożsamości dla poszczególnych państw bałkańskich;

2) dyskursy obejmujące bałkański dyskurs kulturowy i narodowy zarówno na poziomie lokalnym (poszczególne bałkańskie dyskursy kulturowe i narodowe), jak i dwustronnym: dyskurs macedońsko-grecki, serbsko-chorwacki, serbsko-kosowski, jak i na europejskich i dalszych poziomach międzynarodowych (Turcja, Rosja, USA). 
W obydwóch przypadkach analizy są udokumentowane materiałami zaczerpniętymi z oficjalnych wypowiedzi aktorów krajowych i międzynarodowych, badaniami opinii publicznej, doniesieniami medialnymi i oświadczeniami złożonymi przez wpływowych intelektualistów z całego regionu bałkańskiego i międzynarodowych środowisk opiniotwórczych;

3) dyskursy i narracje w porównawczych perspektywach: bałkańskiej, polskiej oraz z pozycji szerszego kręgu europejskiego, pokazujące różnice w odbiorze tych samych wydarzeń, poglądów, stereotypów i mitów w zależności od kraju oraz rolę każdego z nich w kreowaniu dyskursywnego obrazu Bałkanów jako rodzaju tożsamości narracyjnej.

\title{
Zakończenie
}

Typy tożsamości narracyjnych obecnych w państwach pojugosłowiańskich, w tym w Macedonii, mają silny wpływ na rozumienie przynależności politycznej większości społeczeństwa oraz na kształtowanie elit rządzących. Zarówno przedstawiciele pierwszych, jak i drugich wykorzystują opowieści transmedialne do zdobycia i utrzymania władzy. Osiąganiu tych celów sprzyjają stare i rodzące się nowe nacjonalizmy, głównie obecne w wyobrażonych narracjach i postprawdach dotyczących pochodzenia etnicznego, które jednocześnie wyznaczają przynależność do określonej wspólnoty politycznej.

\section{Bibliografia}

Jenkins H., Kultura konwergencji. Zderzenie starych i nowych mediów, tłum. M. Bernatowicz, M. Filiciak, Warszawa 2007.

Kawka M., Macedonian Discourses, Kraków 2016.

Misirkov Krste P., Za makedonckite raboti, Sofia 1903.

Todorova M., Bałkany wyobrażone, przeł. M. Budzińska, P. Szymor, Wydawnictwo Czarne, 2008.

Maciej Kawka

\author{
Creating a Narrative Identity - \\ the Status and Corpus of the Macedonian Language
}

Summary

The real or only the imaginary identities of the nations inhabiting the present territory of the Balkans have an aspect not only real as a combination of events and historical facts as well as contemporary changes, but also the dimension of transmedia tales of Macedonian identity. These two levels of forming or creating identity processes not only co-exist or compete with each other, they also permeate each other. Today, however, this second aspect of creating - often imaginative and self-identifying - transmedia auto-narrations about the origin of identity prevails. They are then an attempt, an effect of mediatisation processes, i.e. mediation of the memory of the past or the pres- 
ent by the media not only in the narrow sense as the press, radio television, the Internet, but also as all memory carriers (from historical sources, museums, monuments, anniversary celebrations to transmedia stories, film, theatre or widely understood art).

In this context, transmedia storytelling are multi-threaded and diverse stories told (mediated) through various forms of communication (film, digital platforms, computer games, comics, etc.) that create a new narrative identity of ethnic communities, nations and societies.

Keywords: Balkans, Macedonia, Macedonian language, transmedia storytelling, narrative identity. 